\title{
Larval density, temperature and biological aspects of Chrysomya megacephala (Diptera: Calliphoridae)
}

[Densidade larval, temperatura e aspectos biológicos de Chrysomya megacephala (Diptera: Calliphoridae)]

\author{
C. Reigada ${ }^{1}$, W.A.C. Godoy ${ }^{2}$ \\ Departamento de Parasitologia - UNESP \\ Distrito de Rubião Júnior \\ 18618-000 - Botucatu, SP \\ ${ }^{1}$ Bolsista da FAPESP \\ ${ }^{2}$ Bolsista do CNPq
}

\begin{abstract}
The effect of larval density on the survival, fecundity and body size at two temperatures in experimental populations of C. megacephala was studied. No effect from simultaneous influence of density and temperature on life history characteristics of C. megacephala was found. Significant effects of density and temperature on survival, fecundity and body size were observed. The importance of these results for the population dynamics of C. megacephala is discussed.
\end{abstract}

Keywords: Chrysomya megacephala, density-dependence, temperature, survival, fecundity

\section{RESUMO}

Analisou-se o efeito de duas densidades larvais e duas temperaturas sobre a sobrevivência, fecundidade e tamanho corpóreo de C. megacephala em condições experimentais. Nenhum efeito simultâneo da densidade e temperatura foi encontrado sobre as variáveis investigadas em C. megacephala. Entretanto, foram observados efeitos isolados significativos da densidade e da temperatura sobre a fecundidade e tamanho corpóreo. A importância desses resultados para a dinâmica populacional de C. megacephala foi discutida.

Palavras-chave: Chrysomya megacephala, dependência da densidade, temperatura, sobrevivência, fecundidade

\section{INTRODUCTION}

Domestic, semi-domestic and wild animals, as well as humans, are subject to various diseases caused by several pathogens transmitted by blowflies when, visiting carcasses, faeces and other excrements to lay their eggs (Greenberg, 1971). In addition, they cause facultative myiasis in humans and animals (Guimarães and Papavero, 1999). Chrysomya megacephala is a blowfly from the Australasian, Palearctic and
Oriental regions, and from South African and Afrotropical Islands (Smith, 1986), which was found in Brazil around 1975, together with two other species, C. putoria and C. albiceps. These species dispersed rapidly throughout the continent, with $C$. megacephla reaching the United States (Wells, 1991). The Chrysomya invasion has apparently caused the displacement of Cochliomyia macellaria, an American native species (Guimarães et al., 1979). Biological invasions frequently produce complex

Recebido em 25 de junho de 2004

Aceito em 17 de abril de 2006

E-mail: reigada@ibb.unesp.br

Apoio FAPESP (01/11235-1) 
interactions on ecological and genetic levels (Brown, 1993).

Among the main biological factors essential to understanding biological invasion, the dynamic behaviour emerges as an important component to evaluate relevant demographic aspects (Hengeveld, 1989). However, dynamic behaviour usually depends on factors associated with demography, such as growth rate and life history characteristics (Uchmanski, 1999). Life history and population growth are subject to high variation among different species and populations (Gotelli, 1995). The causes of variation are usually diverse and depend on the environment and/or biological attributes of each species (Brewer, 1994).

Temperature is probably the most influential environmental factor in the life history of populations, particularly in organisms with short life cycles such as insects (Levine and Levine, 1991). Competitive ability, fecundity, survival rates, in addition to weight and body size, have shown high sensitivity to environmental variations in insect populations, especially in Musca domestica (James and Partridge, 1998). Several studies have focused on evolutionary aspects of population arising at different temperatures in order to analyse geographic changes, natural selection and genetic divergence (Santos et al., 1997). The approach of these studies has conspicuous value in the context of evolutionary biology, as sensible thermal changes can greatly influence the behaviour, ecology and evolution of biological populations (Huey, 1982).

In nature, larvae of blowflies are found in ephemeral substrates such as carrion or dung, usually with large number of individuals exploring the same sources of food (Kneidel, 1984). This situation can produce competitive interactions as a function of density and the external and internal temperature of the substrate, which frequently influence the population dynamics, causing impact on the demography of the species (Brewer, 1994). This study aimed to analyse the effect of larval density on the life cycle characters of $C$. megacephala, at different temperatures, by experimental survival, fecundity and adult body size estimations.

\section{MATERIAL AND METHODS}

Specimens of $C$. megacephala were collected in the vicinities of the campus of the Universidade Estadual Paulista, Botucatu, São Paulo, Brazil to set experimental populations. Adult flies were identified and maintained under laboratory conditions, at $25 \pm 1^{\circ} \mathrm{C}$, in cages covered with nylon $(30 \mathrm{~cm} \times 30 \mathrm{~cm} \times 30 \mathrm{~cm})$, and fed water and sugar ad libitum. Adult females were fed fresh liver to permit complete development of the gonotrophic cycle (Linhares, 1988). Newly hatched larvae of $C$. megacephala were obtained from adult flies kept at constant temperature $\left(25^{\circ} \mathrm{C}\right)$ and $70 \%$ relative humidity, and raised in vials containing ground beef. Two larval densities were set and kept at constant food quantity at different temperatures, $20^{\circ}$ and $30^{\circ} \mathrm{C}$, with three replicates each. Larval densities, with 200 and 1,000 larvae, respectively, simulated low and high densities. In both cases, the larvae were raised on $50 \mathrm{~g}$ of ground beef. The survival was estimated by recording the number of emergent adults. Twenty females from each population were dissected and the number of eggs recorded. Body size was estimated by measuring right wing and tibia. The experiments were performed from March (2001) to September (2001).

Values for survival, fecundity, wing and tibia sizes of males and females were compared by one-way and two-way analyses of variance in order to analyse simultaneously and separately the effects of temperature and densities on the variables (Sokal and Rohlf, 1981).

\section{RESULTS}

No simultaneous significant effects of density and temperature on all life cycle variables investigated in C. megacephala were found and no significant influence of temperature or density on survival was observed (Table 1). However, significant effects of density and temperature were observed on the fecundity, which showed higher values for the density of 200 larvae than for the density of 1,000 larvae $(F=161.3$, $\mathrm{P}<0.001)$ and for temperature at $20^{\circ} \mathrm{C}$ than for temperature at $30^{\circ} \mathrm{C} \quad(\mathrm{F}=25.99, \quad \mathrm{P}<0.0001)$, respectively (Table 2 ). 
Table 1. Survival (percent of adults) of males and females of $C$. megacephala raised in low and high densities at two temperatures

\begin{tabular}{lcc} 
Temperature & $\begin{array}{c}\text { Density of } 200 \\
(\%)\end{array}$ & $\begin{array}{c}\text { Density of } 1000 \\
(\%)\end{array}$ \\
\hline $20^{\circ} \mathrm{C}$ & $40.16 \pm 21.07$ & $47.66 \pm 8.79$ \\
$30^{\circ} \mathrm{C}$ & $51.8 \pm 31.7$ & $48.06 \pm 15.96$ \\
\hline
\end{tabular}

Table 2. Fecundity (percent of eggs) of females of $C$. megacephala raised in low and high densities at two temperatures

\begin{tabular}{lcc}
\hline Temperature & $\begin{array}{c}\text { Density of } 200 \\
(\%)\end{array}$ & $\begin{array}{c}\text { Density of } 1000 \\
(\%)\end{array}$ \\
\hline $20^{\circ} \mathrm{C}$ & $247.03 \pm 9.8$ & $175.21 \pm 16.56$ \\
$30^{\circ} \mathrm{C}$ & $232.34 \pm 21.93$ & $159.67 \pm 13.55$ \\
\hline
\end{tabular}

Significant influence of both temperature $(\mathrm{F}=11.1, \quad \mathrm{P}<0.001)$ and density $(\mathrm{F}=48.31$, $\mathrm{P}<0.0001)$ on the wing size was observed, with males from the density of 200 larvae exhibiting larger wings than males from the density of 1,000 larvae at both temperatures (Table 3). Similar to densities, males raised at $20^{\circ} \mathrm{C}$ exhibited larger wings than males kept at $30^{\circ} \mathrm{C}$, for both densities.

Table 3. Wing size of males and females of Chrysomya megacephala raised in low and high densities at two temperatures

\begin{tabular}{lccc}
\hline Sex & Temperature & $\begin{array}{c}\text { Density of } 200 \\
(\mathrm{~mm})\end{array}$ & $\begin{array}{c}\text { Density of } 1000 \\
(\mathrm{~mm})\end{array}$ \\
\hline \multirow{2}{*}{ Male } & $20^{\circ} \mathrm{C}$ & $8.0 \pm 0.11$ & $7.42 \pm 0.08$ \\
& $30^{\circ} \mathrm{C}$ & $7.73 \pm 0.49$ & $7.09 \pm 0.28$ \\
\multirow{2}{*}{ Female } & $20^{\circ} \mathrm{C}$ & $7.88 \pm 0.27$ & $7.27 \pm 0.13$ \\
& $30^{\circ} \mathrm{C}$ & $7.74 \pm 0.35$ & $7.17 \pm 0.31$ \\
\hline
\end{tabular}

In females of $C$. megacephala, only the density factor significantly influenced the wing size $(\mathrm{F}=21.77, \mathrm{P}<0.0001)$. Hence, wing size was larger in the density of 200 larvae than in the density of 1,000 larvae at both temperatures (Table 3). For males of $C$. megacephala, the density was also the only significantly influential factor on the tibia size $(\mathrm{F}=36, \mathrm{P}<0.0001)$, with tibia size larger in the density of 200 larvae than in the density of 1,000 larvae at both temperatures (Table 4). Density was also the only significantly influential factor on tibia size in females $(\mathrm{F}=17.76 . \mathrm{P}<0.001)$, with tibia size larger in the density of 200 larvae than in the density of 1,000 larvae at both temperatures (Table 4).
Table 4. Tibia size of males and females (mm) of Chrysomya megacephala raised in low and high densities at two temperatures

\begin{tabular}{lccc}
\hline Sex & Temperature & $\begin{array}{c}\text { Density of } 200 \\
(\mathrm{~mm})\end{array}$ & $\begin{array}{c}\text { Density of } 1000 \\
(\mathrm{~mm})\end{array}$ \\
\hline \multirow{2}{*}{ Male } & $20^{\circ} \mathrm{C}$ & $2.58 \pm 0.05$ & $2.3 \pm 0.04$ \\
& $30^{\circ} \mathrm{C}$ & $2.53 \pm 0.11$ & $2.28 \pm 0.06$ \\
\multirow{2}{*}{ Female } & $20^{\circ} \mathrm{C}$ & $2.54 \pm 0.06$ & $2.33 \pm 0.03$ \\
& $30^{\circ} \mathrm{C}$ & $2.48 \pm 0.08$ & $2.35 \pm 0.18$ \\
\hline
\end{tabular}

\section{DISCUSSION}

Survival, fecundity and body size have been analyzed in flies by studies which focused on intra- and inter- specific competition (Reis et al., 1994). Most of the results show that the competitive processes, which act on the species, may induce changes in population behaviour. It is known that the larval competition for limited resources can be scramble or contest types (Birch, 1957). In scramble, all individuals are equally affected. It occurs when some species decreases the environmental carrying capacity, stimulating the homogeneously partition of resources among individuals (De Jong, 1976). Chrysomya species usually exhibit scramble competition (Reis et al., 1996), but depending on alternative mechanisms, such as intraguild predation, detected in C. albiceps (Polis et al., 1989), the type of pattern can be changed from scramble to contest (Polis et al., 1989).

The results showed that at different densities (200 and 1,000), survival did not show a significant difference. On the other hand, the analysis suggests that the increase of intraspecific competitor numbers did not influence the survival in $C$. megacephala. However, density influenced both fecundity and body size of adults. Density dependence has been frequently studied in insect populations, including blowflies (Reis et al., 1996). Intraspecific competition has been investigated in C. megacephala, C. putoria and Cochliomyia macellaria, with results suggesting its negative influence on survival and fecundity, but in different ranges of densities (Reis et al., 1994; Reis et al., 1996).

A detailed sensitivity analysis of population dynamics by using mathematical models has shown that the most sensitive demographic parameter for $C$. megacephala in terms of 
influence on dynamics is not survival (Godoy et al., 1996). Thus, these results are in accordance with those obtained by Godoy et al. (1996). Fecundity is the most sensitive parameter for $C$. megacephala, as it can cause significant changes in behavioural dynamics, leading the population from a two-point limit cycle to a one-point stable equilibrium (Godoy et al., 1996). In a very recent study focusing on intra- and interspecific competition among C. albiceps, C. megacephala and C. macellaria (Rosa et al., 2004) with different amounts of food, it was observed that C. megacephala, C.macellaria and C. albiceps exhibited similar survival at densities of both 200 and 1,000 with either 25 or $50 \mathrm{~g}$ of food for third instar larvae. In this experimental design, $50 \mathrm{~g}$ of food were used to test the effect of density and temperature. This condition, associated with density sets, could explain the absence of significant difference in survival.

Temperature may act on life-cycle stages, limiting the distribution of species by decreasing survival, reproduction, development and interactions with other organisms such as competition, predation or parasitism (Krebs, 2001). Temperature usually influences the biological variables which determine the body size. In males of $C$. megacephala, both temperature and density influenced its wing size. In females, only the density influenced this variable. There is no apparent explanation for this difference, but it is clear that males exhibit more sensitivity to thermal variations than females, since a decrease in terms of body size was detected only for them.

These results are not similar to those of Rosa et al. (2004), who observed that male body size was not affected by larval densities. However, the experimental design performed by Rosa et al. (2004) was used to investigate interspecific competition for food and did not include variations in temperature, which may explain the different results. Significance was only detected, suggesting that the simultaneous effect of density and temperature did not emerge in the experiments.

The variation of life cycle characters was analyzed in several groups of insects (Honek, 1993), including blowflies (Reis et al., 1994), showing a strong correlation between body size and potential fecundity (Honek, 1993; Reis et al.,
1994). In addition, competition for food affects the fitness of adults with implications for population dynamics and demography (Hastings, 1997). Analyses of competition under experimental conditions are important for community studies, primarily when food scarcity is a predominant factor.

\section{REFERENCES}

BIRCH, L.C. The meaning of competition. Am. Nat., v.91, p.5-18, 1957.

BREWER, R. The science of ecology. Forth Worth: Saunders College Publishing, 1994. $773 \mathrm{p}$.

BROWN, M.W. Population dynamics of invading pests: Factors governing success. In: KIM, K.C.; MCPHERON, B.A (Eds.). Evolution of insect pests: Patterns of variation. New York: John Wiley \& Sons, 1993. p.203-218.

DE JONG, G. A model of competition for food. I. Frequency dependent viabilities. Frequency dependent viabilities. Am. Nat., v.110, p.10131027, 1976.

GODOY, W.A.C.; ZUBEN, C.J.V.; REIS, S.F. Dynamics of experimental populations of native and introduced blowflies (Diptera: Calliphoridae): mathematical modelling and the transition from asymptotic equilibrium to bounded oscillations. Mem. Inst. Oswaldo Cruz., v.91, p.641-648, 1996.

GOTELLI, N.J. A primer of ecology. Sunderland, MA: Sinauer Associates, 1995. 206 p.

GREENBERG, B. Flies and disease. Ecology, classification and biotic associations. New Jersey: University Princeton, 1971. 856p.

GUIMARÃES, J.H.; PAPAVERO, N. Myiasis in man and animals in the neotropical region. São Paulo: Plêiade, 1999. 308p.

GUIMARÃES, J.H.; PRADO, A.P.; BURALLI, M. Dispersal and distribution of three newly introduced species of Chrysomya RobineauDesvoidy in Brasil (Diptera, Calliphoridae). Rev. Bras. Entomol., v.23, p.245-255, 1979.

HASTINGS, A. Population biology, concepts and models. New York: Springer-Verlag, 1997. $220 \mathrm{p}$. 
HENGEVELD, R. Dynamics of biological invasions. London: Chapman \& Hall, 1989. $160 \mathrm{p}$.

HONEK, A. Intraspecific variation in body size and fecundity in insects. A general relationship. Oikos, v.66, p.483-492, 1993.

HUEY, R.B. Temperature, physiology, and the ecology of reptiles. In: GANS, C.; POUGH, F. H (Eds.). Biology of the Reptilia. Cambridge, UK, 1982. p.25-67.

JAMES, A.C.; PARTRIDGE, L. Geographic variation in competitive ability in Drosophila melanogaster. Am. Nat., v.151, p.530-537, 1998.

KNEIDEL, K.A. Competition and disturbance in communities of carrion breeding diptera. $J$. Anim. Ecol., v.53, p.849-865, 1984.

KREBS, C.J. Ecology: the experimental analysis of distribution and abundance. New York: Harper \& Row, 2001. 715p.

LEVINE, O.S.; LEVINE, M.M. Houseflies (Musca domestica) as mechanical vectors of Shigellosis. Infect. Immun., v.31, p.445-452, 1991.

LINHARES, A.X. The gonotrophic cycle of Chrysomya megacephala (Diptera: Calliphoridae) in the laboratory. Rev. Bras. Entomol., v.32, p.383-392, 1988.

POLIS, G.A.; MYERS, C.A.; HOLT, R.D. The ecology and evolution of intraguild predation: potential competitors that eat other? Ann. Rev. Ecol. Syst., v.20, p.297-330, 1989.
REIS, S.F.; STANGENHAUS, G.; GODOY, W.A.C. et al. Variação em caracteres bionômicos em função da densidade larval em Chrysomya megacephala e Chrysomya putoria (Diptera, Calliphoridae). Rev. Bras. Entomol., v.38, p.3346, 1994.

REIS, S.F.; TEIXEIRA, M.A.; VON ZUBEN, F.J. et al. Theoretical dynamics of experimental populations of introduced and native blowflies (Diptera: Calliphoridae). J. Med. Entomol., v.33, p.537-544, 1996.

ROSA, G.S.; CARVALHO, L.R.; GODOY, W.A.C. Survival rate, body size and food abundance in pure and mixed blowfly cultures. Afr. Entomol., v.12, p.97-105, 2004.

SANTOS, M.; BORASH, D.J.; JOSHI, A. et al. Density-dependent natural selection in Drosophila: evolution of growth rate and body size. Evolution, v.51, p.420-432, 1997.

SMITH, K.G.V. A manual of forensic entomology. Oxford: University Printing House, 1986. 205p.

SOKAL, R.R.; ROHLF, F.J. Biometry. New York: WH Freeman \& Company, 1981. 859p.

UCHMANSKI, J. What promotes persistence of a single population: an individual bases model. Ecol. Mod., v.115, p.227-241, 1999.

WELLS, J.D. Chrysomya megacephala (Diptera: Calliphoridae) has reached the continental United States: review of its biology, pest status and spread around the world. J. Med. Entomol., v.28, p.471-473, 1991. 